\title{
Social representations of the elderly about HIV/AIDS
}

\author{
Representações sociais de idosos soropositivos acerca do hiv/aids \\ Representaciones sociales de ancianos soropositivos acerca del VIH/SIDA
}

Brígida Maria Gonçalves de Melo Brandão'

ORCID: 0000-0002-2296-6688

Rebeca Coelho de Moura Angelim'

ORCID: 0000-0002-4284-1444

Sergio Corrêa Marques"

ORCID: 0000-0003-2597-4875

Denize Cristina de Oliveira"

ORCID: 0000-0002-0830-0935

Regina Célia de Oliveira'
ORCID: 0000-0002-6559-5872

Fátima Maria da Silva Abrão'

ORCID: 0000-0003-3254-2851

'Universidade de Pernambuco, Faculdade de Enfermagem Nossa Senhora das Graças. Recife, Pernambuco, Brazil. "Universidade do Estado do Rio de Janeiro, Faculdade de Enfermagem. Rio de Janeiro, Rio de Janeiro, Brazil.

How to cite this article: Brandão BMGM, Angelim RCM, Marques SC, Oliveira DC Oliveira RC, Abrão FMS. Social representations of the elderly about HIV/AIDS. Rev Bras Enferm. 2019;72(5):1349-55. doi: http://dx.doi.org/10.1590/0034-7167-2018-0296

Corresponding Author:

Brígida Maria Gonçalves de Melo Brandão E-mail: bri.melo@hotmail.com

Submission: 05-10-2018

Approval: 02-03-2019

\section{ABSTRACT}

Objective: to understand the representational content about HIV/AIDS among seropositive elderly people. Method: a qualitative study carried out from April to May 2017, in the city of Recife/PE, with 48 seropositive elderly people, through a semi-structured interview. The Social Representations Theory was used as theoretical framework and the method of lexical analysis through IRAMUTEQ software. Results: it was observed that the social representation of HIV is structured around the proximity of death and that it is a disease of restricted groups, leading to feelings of sadness. On the other hand, it is evident a transformation of the representation linked to the reified knowledge, leading to the process of naturalization of the disease. Final considerations: it is concluded that the elderly living with HIV, when they undergo a process of reframing about the disease, become more flexible to deal with their condition of seropositivity.

Descriptors: Social Perception; HIV; Acquired Immunodeficiency Syndrome; Aged; Psychology, Social.

\section{RESUMO}

Objetivo: apreender os conteúdos representacionais acerca do HIV/Aids entre pessoas idosas soropositivas. Método: pesquisa qualitativa, realizada de abril a maio de 2017, no município de Recife/PE, com 48 pessoas idosas soropositivas, por meio de entrevista semiestruturada. Utilizou-se a Teoria das Representações Sociais como referencial teórico e o método de análise lexical através do software IRAMUTEQ. Resultados: observou-se que a representação social do HIV se estrutura em torno da proximidade da morte e de que é uma doença de grupos restritos, levando a sentimentos de tristeza. Por outro lado, evidencia-se uma transformação da representação ligada ao conhecimento reificado, conduzindo ao processo de naturalização da doença. Considerações finais: conclui-se que os idosos que vivem com HIV, ao passarem por um processo de ressignificação acerca da doença, se tornam mais flexíveis para lidar com a sua condição de soropositividade. Descritores: Percepção Social; HIV; Síndrome de Imunodeficiência Adquirida; Idoso; Psicologia Social.

\section{RESUMEN}

Objetivo: aprehender los contenidos representacionales acerca del VIH/SIDA entre personas mayores seropositivas. Método: la investigación cualitativa, realizada de abril a mayo de 2017, en el municipio de Recife/PE, con 48 personas ancianas seropositivas, por medio de una entrevista semiestructurada. Se utilizó la Teoría de las Representaciones Sociales como referencial teórico y el método de análisis léxico a través del software IRAMUTEQ. Resultados: se observó que la representación social del VIH se estructura en torno a la proximidad de la muerte y de que es una enfermedad de grupos restringidos, llevando a sentimientos de tristeza. Por otro lado, se evidencia una transformación de la representación ligada al conocimiento reificado, conduciendo al proceso de naturalización de la enfermedad. Consideraciones finales: se concluye que los ancianos que viven con $\mathrm{VIH}$, al pasar por un proceso de resignificación sobre la enfermedad, se vuelven más flexibles para lidiar con su condición de seropositividad.

Descriptores: Percepción Social; VIH; Síndrome de Inmunodeficiencia Adquirida; Anciano; Psicología Social. 


\section{INTRODUCTION}

Human Immunodeficiency Virus (HIV) infection has evolved from a fatal condition to a chronic disease condition, leading to increased survival of HIV-infected individuals, resulting in premature aging of this population ${ }^{(1-2)}$.

Although the highest concentration of Acquired Immunodeficiency Syndrome (AIDS) cases in Brazil is in individuals between the ages of 25 and 39, a change in the course of the epidemic in recent years has been observed. The epidemiological profile has shown a significant increase of cases per year, in the age group of 50 years or more, in both genders ${ }^{(3-4)}$. In this context, it should be noted that, according to the Joint United Nations Programme on HIV/AIDS (UNAIDS), patients with positive serology for HIV from the age of 50 can already be considered as elderly ${ }^{(5)}$.

The prevalence of HIV-infected people aged 50 and over is increasing rapidly. In addition, HIV-infected individuals may be more vulnerable to age-related conditions. There is increasing evidence that the prevalence of comorbidities and risk factors for chronic diseases are very common in HIV patients aged 50 years or older and increase with age. Moreover, it is higher in the HIVinfected population when compared to uninfected individuals ${ }^{(1,6)}$.

Thus, it is important to understand the particular psychosocial aspects of older people with HIV, how they view and think about the disease and its impacts on their lives. This is so that these data serve as the basis for the planning of an assistance that values this group in its singularities and better contemplates its social and health needs.

The group social representation on an object is shaped by the way individuals construct, perceive and deal with the disease, being related to their world view. This is largely influenced by socially constructed attitudes, beliefs, and values, involving information from both common sense and scientific thinking ${ }^{(7)}$.

Thus, considering the subject as the author of their reality, from the patterns traced by the social group, it is important to base this study in the light of Social Representation Theory. This theory consists of a system of interpretation of reality, which comprises a certain phenomenon and therefore governs the relations of individuals with the world and with others. It also guides their behavior and serves as a foundation and instrument to direct and facilitate relations with the environment, people and the social world ${ }^{(8)}$.

\section{OBJECTIVE}

To understand the representational content about HIV/AIDS among seropositive elderly people.

\section{METHOD}

\section{Ethical aspects}

The ethical and legal principles of research involving human beings were respected, according to Resolution 466/2012 of the National Health Council, having been approved by the Research Ethics Committee of the Oswaldo Cruz University Hospital's Hospital Complex/Pernambuco Emergency Room (CEP HUOC)
PROCAPE - Complexo Hospitalar do Hospital Universitário Oswaldo Cruz/Pronto Socorro Cardiológico de Pernambuco).

\section{Theoretical-methodological framework}

This study was based on the procedural approach of Social Representations Theory (SRT). Social representation is "a form of knowledge, socially elaborated and shared, with a practical objective, and that contributes to the construction of a reality common to a social set" ${ }^{\prime \prime(7)}$.

\section{Type of study}

This is an exploratory-descriptive study with a qualitative approach.

\section{Methodological procedures}

\section{Study setting}

This study was developed in two Specialized Care Services (SAE - Serviços de Assistência Especializada) in HIV/AIDS located in public hospitals in the Metropolitan Area of Recife, Pernambuco State.

\section{Data source}

In this study, 48 intentionally chosen elderly individuals, who met the following inclusion criteria: age equal or superior to 50 years (since this research adopted the concept of HIV-positive elderly proposed by UNAIDS, as mentioned in the introduction) with a diagnosis of HIV/AIDS for at least 6 months and that they had an outpatient follow-up in one of the SAE included in the research. People without cognitive conditions were excluded from this study to participate.

\section{Collection and organization of data}

Data collection was performed from April to May 2017, through a sociodemographic and clinical questionnaire, and a semi-structured interview script containing questions regarding the contents of the social representation of HIV/AIDS, discovery, meaning and revelation of the diagnosis and about the daily life after the diagnosis.

The interviews had the audio recorded, with the consent of the participants, with later corpus transcription and preparation for analysis. The average duration of each interview was 24 minutes. In order to preserve the identity of the participants, it was decided to identify them with the letter "I", from the word Interviewee, next to the sequential number of the interview (Example: I1).

\section{Data analysis}

After database organization, it was inserted and processed through the Interface de Rpour lês Analyses Multidimensionnelles de Textes et de Questionnaires (IRAMUTEQ) software, in which a brief description of its contents was obtained. Subsequently, we opted for the analysis using the Descending Hierarchical Classification (DHC).

Through the DHC, each text was evaluated and divided into text segments, which were classified according to their vocabulary, constituting lexical classes. The contents of two classes that deal with 
representational elements of seropositive elderly people about HIV/ AIDS, the discovery and the impact of the diagnosis were analyzed and discussed, since they were the objects cut out for discussion. The following categories were created:"HIV/AIDS discovery and diagnosis impact" and "Representational content attributed to HIV/AIDS".

\section{RESULTS}

The sociodemographic profile of the study participants showed that they were aged between 51 and 72 years. $31.2 \%$ were in the 61-65 age group, $58.3 \%$ were males, $39.6 \%$ were single, $75.0 \%$ were heterosexual, $41.7 \%$ had incomplete middle and elementary school, $47.9 \%$ were Catholic and $29.2 \%$ had a diagnosis time between 5 and 10 years.

Data analysis allowed the identification of two categories: "HIV/ AIDS discovery and diagnosis impact"; and "Representational content attributed to HIV/AIDS".

\section{HIV/AIDS discovery and diagnosis impact}

The first category covers factors related to the form of contamination and the process of HIV/AIDS discovery, as well as the initial impact of the diagnosis on the lives of seropositive elderly.

The main form of HIV contamination, according to the reports, was the sexual route, usually derived from stable relationships.

[...] He used to cheat on me, I was already sick and he knew, I did not know. After seeing that he already knew and hid from me, I left him. He continues to transmit it to several people [...] (I17)

I have never imagined, I have never thought even in my worst nightmares that he was going to get a disease of this type and transmit it to me. It was very difficult, my life was just crying a river. [...] At one time or another, when I remember that I have it, I start to cry, to hurt myself, to think of my husband with anger. (I26)

She told me that she did not like having sex with condom; she came to argue that we had been together for some time and that we did not need it anymore. [...] Her younger son had to have a nose surgery and one of those tests he did showed he had HIV. It was necessary to take the exam on her as well and the result gave her. She told me to do it and then the bad news came. (141)

In relation to the impact of the discovery of seropositivity to HIV, the reports of elderly people who adopted a negative attitude, with reactions directed to depression, fright, shock, suffering, trauma and possibility or fear of dying.

When the result came, it was sad, I lost everything in my life. (117)

I thought I would die. (I20)

I was scared, I cried a lot and almost went into depression. (142)

It was traumatic. I went first on the beach, sat there crying, thinking I was going to die. At that time there were 3 months to die, at most. (I30)

I cried a lot, I was knocked over, besides noticing people's biased gaze. (I32)
However, there are cases in which the elderly living with HIV/ AIDS seem to be indifferent to the diagnosis:

I did not even care; I faced it normally. (I13)

Since I have a very open mind for these contagious diseases, I faced it as a fatality; I minded my own business. (124)

I was neutral, silent. I was not amazed like most people do. (I43)

There are also situations where, at first, there was shock and sadness, but then the elderly felt better and resigned:

I had many nightmares, I felt depressed, but soon afterwards it improved and I became optimistic. (I1)

At the time the world fell, but then, I sat down and thought I'm going to live with him [HIV], he will not bring me down' and even today if I have anything [health problem] I think it was something I ate that did me wrong. [...] nothing that I have I relate to it [HIV]. (I27)

\section{Representational content attributed to HIV/AIDS}

The second category reveals knowledge, feelings and images built by HIV-positive older people, expressing how the group symbolizes the disease.

Some elderly people understand HIV/AIDS as dangerous, fearful and similar to a death sentence.

[...] I think it is a disease that is not good and has no solution. The person with HIV cannot get well. I cry a lot because I think I'm going to die anytime. (13)

For me, AIDS is a deadly disease; is something that can lead to death. In my life, having HIV is embarrassing because people have a lot of prejudice and it causes a lot of suffering in my life. (121)

Like I said, it's a horrible thing, it's sad, it's a disease in which we are restricted to many things. We relate to people, but it is not normal. [...] It means death to me. (I28)

It is worth emphasizing that the representations of the cruel and massacring facet of HIV/AIDS remain in the socio-cognitive constructions of seropositive elderly, making reference to the beginning of the HIV/AIDS epidemic transmission. In the media, the constant difficulties and characteristics of famous people affected by this phenomenon were disclosed, characterizing images that had impact on the disease and the virus.

I think AIDS is a very, very cruel disease. That Cazuza [Cazuza was a Brazilian singer and songwriter] boy and several artists at the time died of AIDS. It is a very dangerous disease. (I2)

HIV is something that if you do not care the person with HIV dies. If there are artists who had the money died of it, then I thought 'and I that I am poor? I'm definitely going to die'. (I20)

I know a lot of people have already died of this, I kept asking, 'Oh, my God, will this happen to me?' I thought I was going to die at that moment because the way the situation was, a lot of people dying of it. I was afraid. (I38) 
It was also identified aspects from the beginning of the epidemic, such as the perception that HIV infection is due to risk groups or socially depredated behaviors. This process resembles the attribution of contamination as an "other's" responsibility and the result of moral failure. This aspect is expressed in surprise and misunderstanding when someone who judges himself to be right and of unblemished conduct discovers that he has HIV, as the speech below:

Is very difficult. When you are a man, people think straight away that you are gay or that you are drugged and like to party. But with me it was not like that, I never strung anyone along, I have always been a serious man and respectful with my relationships, but ithappened. (113)

They did all kinds of tests on me of all kinds of diseases. Since I did not use drugs and I did not have sexual relations with homosexual, I ruled that it was this business. Besides, I was married and did not have a promiscuous life. (124)

I've always been a right woman. [...] I did not expect this because I did not like to party, I was always a seamstress, I always worked at home, I only related to my husband. (142)

It is observed through the reports that the knowledge reified about HIV is incorporated into the representation, through content that refers to the forms of transmission, the possibility of living with the virus and treating it. But, also, the association with risk groups remains in the representations of this group. This representational permanence is probably determined by the strong stigmatizing content still present in AIDS representations.

I know that through the kiss does not get, because it does not transmit through saliva, but through sex, yes. (I15)

Nowadays, I already see how an epidemic out of control, little prevention and that has a treatment that has no cure, but has antiretroviral drug to control. Before, it was death sentence, but today, no, because if I treat myself, I can live quietly with him [HIV]. (I32)

Still in this line of thought, it is emphasized that the advent of the universal and free availability of Antiretroviral Therapy (ART) may have collaborated with the naturalization of living with the virus, being considered as a disease equal to any other.

For me, it's normal, I'll give you an example. There are worse diseases than HIV, like diabetes and cancer. (I8)

For me, this HIV today represents nothing. I say before God that it does not represent anything at all. It's like it's like high blood pressure and low blood pressure, ifyou do not take the medication, of course you will feel changed. So for me, it's nothing, I'm a normal person. (119)

There is a person with HIV who despairs, and I, the day I discovered that I was, I put it on my head that if I had discovered that I had diabetes, I would die with diabetes because it also has no cure. (I27)

\section{DISCUSSION}

In this study, it was possible to understand and describe concepts and feelings of elderly people seropositive to their serological condition. Thus, it was found that the negative impact of HIV discovery may be linked to the social representation of HIV/AIDS as a dangerous disease permeated by the proximity of death, even though the naturalization of the disease and virus. In addition, there were feelings of disappointment and frustration in finding that the transmission was by the spouse.

One of the justifications for HIV transmission is premarital or extramarital affairs, in which one of the spouses engages with someone and does not use protection, thus favoring the virus transmission. In the case in question, it is as if the person were vulnerable to HIV contamination, because the stable relationship or the marriage represents love and respect, causing a state of trust and fidelity to the partner, which can lead to non-adoption of condom use ${ }^{(9)}$.

Studies show that ignorance of the serological status of an individual with HIV may contribute to HIV exposure. Thus, it is necessary to incorporate some strategies that can reduce such exposure, such as access to prevention methods, frequent use of condoms, routine HIV serological testing, and HIV/AIDS awareness) to reveal their diagnosis, particularly for the fixed partners ${ }^{(10-11)}$.

Regarding the meanings attributed to HIV/ IDS, it should be emphasized that culture and social groups have the function of transmitting values to the individuals who participate. Thus, through the elderly statements, it is observed that even after more than three decades of the onset of the epidemic, the social representation linked to the beginning of the epidemic still permeates this group, which is the belief that HIV/AIDS is associated near death, fear of dying, sadness and suffering.

A study carried out with seropositive elders also found that one of the main representational contents refers to AIDS as an incurable disease that can lead to death ${ }^{(12)}$. In a study with health professionals about the impact of the discovery of HIV in the elderly, it was mentioned that the main attitudes and positions are also negative, considering that the elderly respond with sadness, denial, embarrassment and surprise. These impacts end up making the elderly socially isolated, compromising their daily activities and their relationship with groups and individuals ${ }^{(13)}$.

Negative attitudes are expected, since the discovery of seropositivity is still considered a critical moment permeated by anguishes and insecurities, because although there is treatment and control, there is still no cure, which helps to cultivate beliefs and interpretations about the HIV/AIDS, how to consider it a synonym of death. In addition, the discovery of HIV may imply a process of disruption of the subject's identity, because HIV requires a reorganization of the lifestyle and seriousness in the treatment, so that there is a control, which represents another challenge, mitigating the suffering, especially in the beginning ${ }^{(14-16)}$.

Representational content of the elderly focused on the cruelty of HIV/AIDS, established from examples of famous people divulged by the media, constructing the perception of cruel and lethal disease ${ }^{(17)}$. The media has great influence on the construction of social representations of HIV/AIDS. Jodelet ${ }^{(7)}$ even went so far as to say that "social representations circulate in discourses, are brought about by words and conveyed in messages and media images", that is, as the media was responsible for the announcement of the appearance and the first news about this phenomenon, everything that was disclosed contributed to elaborate the image of the disease and the PLHIV.

Also identified in this research were the existences of symbolic constructs that relate HIV to homosexuality or promiscuity. This 
image is formed by elements of the consensual universe of social representations. That is, coming from knowledge elaborated and shared at the beginning of the epidemic, when most of the cases were observed in these social groups.

It is common for an individual to assign labels to something that is not known to him completely. Thus, when considering HIV distant from its reality and assigning the label of connection to promiscuity, a stigma eventually emerges, giving rise to negative elements and devaluation of PLHIV ${ }^{(18)}$. When considering that only a certain group can have HIV, the person puts himself in a situation of advantage, demeaning the other. Thus, the image of HIV/AIDS centered in certain groups provokes a perception of invulnerability and distance from the disease, especially in cases where the individual is in a stable relationship ${ }^{(19)}$.

Regarding the impact of the diagnosis, it was possible to identify, in addition to feelings of frustration, elderly individuals who were either indifferent or resigned after diagnosis. This happens because it is common that the news of seropositivity causes, at first, a sense of bitterness and lack of direction. However, after the initial impact, it is possible that a reorganization takes place in the face of the new reality, and that the PLHIV starts to face its condition better, being optimistic and relying on new perspectives for his life ${ }^{(20)}$. On the other hand, feelings about diagnosis are also determined by the representation of HIV/AIDS, making the discovery process more or less suffer.

It was possible to show that some elderly people face the indifferent or resilient discovery of HIV, which may be associated with the social representation of HIV/AIDS as a normal disease and compared to other chronic diseases, as evidenced by disease and treatment.

A social representation always symbolizes something, allowing a symbolic construction and constituting a new reading of the object it represents, influencing the affective manifestations, ways of thinking, practices and behaviors of each person, consistent with their social group ${ }^{(7)}$. Thus, the manifestations in front of the diagnosis can undergo transformations during the conviviality with the disease, since the subject starts to integrate new knowledge about HIV. So, it incorporates new conduits that can be guided according to the scientific advances.

After the introduction of the ART, allowing a greater survival of PLHIV, HIV/AIDS had a status of chronic disease, distancing the old representations of lethal disease. In this way, treatment became responsible for the longevity and higher quality of life of individuals. As a result, HIV/AIDS has often been considered as normal, equated with other chronic diseases and considered as something easier to coexist with than other health problems.

The study demonstrated that, over time, PLHIV developed discourses of better acceptance, reflection and adaptation to the new reality, placing expectations broadened in the future, with the possibility of imagining themselves well in different situations of the social setting in which it is inserted. This attitude reveals the quest to live with quality of life, even in the face of uncertainties ${ }^{(21)}$.

Other research reveals that the decision to live one day at a time and make plans can stem from the incessant desire not to dwell on the past, as there is no possibility of going back and avoiding HIV contamination. Therefore, PLHIV should only concern themselves with the present, the future, and maintain the control and stability of the disease ${ }^{(22)}$.
In the list of positive attitudes towards HIV/AIDS, it is also possible to cite the reframing of the disease for some elderly people. Reframing provides an inner transformation, modifying feelings and actions towards oneself and the other through a reorientation of practices and way of meaning the world, impacting the transition from a connotation of pain and anguish to an attitude of strength and coping ${ }^{(23)}$.

In the midst of the naturalization or HIV/AIDS reframing as content of the social representations of HIV/AIDS linked to the reified knowledge. Today, the disease is considered to be chronic, unlike the 1980s, when AIDS was seen as an acute disease because it manifested itself rapidly and soon led to death ${ }^{(24)}$. In this sense, it is important that health professionals overcome the barriers that interfere with the provision of care for PLHIV, deconstructing the meanings that defined the epidemic at the outset and linking HIV/AIDS with the new meaning of a chronic condition, allowing its social reframing and the construction of care strategies dedicated to patients ${ }^{(25)}$.

This possibility of living longer has triggered a process of HIV normalization by PLHIV, which signals the transformation of the contents of social representation. It also substitutes the concept of death for life, anchoring HIV/AIDS in pathologies such as DM and hypertension, with the conception that although it is for the rest of life, there is control through drugs ${ }^{(26)}$.

It is worth emphasizing that the naturalization of HIV/AIDS is evidenced by a scientific discourse, where knowledge is impacted by the search for empirical evidence ${ }^{(27)}$. From this, knowledge derived from the reified universe is now incorporated into common sense, transforming it into meaningful knowledge for daily life ${ }^{(28)}$. This attitude is evident in this study when the elderly demonstrate the knowledge of the forms of transmission and that it is possible to live with the virus and receive treatment, incorporating the idea that it is something normal.

\section{Study limitations}

This study had as a limitation the fact that the majority of the participants presented low level of education, with consequent difficulty in producing a more detailed speech on the object of study, which could have allowed an analysis of other constituent elements of the representation of AIDS, rescuing the representational field.

\section{Contributions to the fields of Nursing, Health or Public Policy}

The contribution of this study to the scientific community was highlighted, especially the nursing team and other professionals who work in SAE. Knowing the social representations about HIV/AIDS, as well as the impact of the diagnosis and the ways in which the elderly live with the disease, it is possible to identify the main points to be worked on. Thus, to design a more effective assistance, aiming at compliance with treatment and, therefore, favoring a better prognosis and contributing to the improvement or maintenance of the quality of life of seropositive elderly.

\section{FINAL CONSIDERATIONS}

Finally, investigating the social representations about HIV/AIDS, as well as the impact of the diagnosis on the lives of the seropositive elderly people, were identified feelings of disappointment, sadness and despair. However, there were elderly individuals who 
were either indifferent or resigned to the diagnosis. HIV/AIDS still exists as something worthy of fear, highlighting the influence of the media in the construction of these representations, and also the idea that HIV/AIDS is a restricted group disease.

HIV reframing served to reorient their behaviors and attitudes, by identifying representational contents linked to reified knowledge, which refer to the possibility of treatment and coexistence with the virus. This reflects a greater survival, leading to the naturalization process of living with HIV/AIDS and deconstructing the concept of lethal to consider it a chronic disease, like any other.
Health professionals should pay attention to the possibility of a cognitive fragility in this group associated with age. Neurocognitive disturbances may have repercussions on compliance with the therapeutic regimen, which may lead to less protection during the sexual act, leading to a greater ease of virus dissemination.

Overall, the data reinforce the need to expand actions to promote and protect the health of older people by providing guidance on protected sexual practices, raising doubts about HIV/AIDS and demystifying misconceptions.

\section{REFERENCES}

1. Fontela C, Castela J, Juanbeltz R, Martínez-Baz I, Rivero M, O'Leary A, et al. Comorbidities and cardiovascular risk factors in an aged cohort of HIV-infected patients on antiretroviral treatment in a Spanish hospital in 2016. Postgrad Med J [Internet]. 2018 [cited 2018 Apr 01];130(3):317-24. Available from: https://www.ncbi.nlm.nih.gov/pubmed/29486621

2. Ronel J, Dinkel A, Wolf E, Marten-Mittag B, Mueck B, Mayr C, et al. Anxiety, depression, and health-related quality of life in aging people living with HIV compared to diabetes patients and patients with minor health conditions: a longitudinal study. Psychol Health Med [Internet]. 2018 [cited 2018 Apr 01];23(1):1-8. Available from: https://www.ncbi.nlm.nih.gov/pubmed/29430957

3. Okuno MFP, Gomes AC, Meazzini L, Scherrer Jr G, Belasco Jr D, Belasco AGS. Qualidade de vida de pacientes idosos vivendo com HIV/Aids. Cad Saúde Pública [Internet]. 2014 [cited 2018 Apr 02];30(7):1551-9. Available from: http://www.scielo.br/pdf/csp/v30n7/0102-311X-csp-30-7-1551.pdf

4. Ministério da Saúde (BR). Boletim Epidemiológico - Aids e DST [Internet]. 2015 [cited 2018 Apr 02]. Available from: http://www.aids.gov.br/ pt-br/pub/2015/boletim-epidemiologico-hivaids-2015

5. Joint United Nations Programme on HIV/AIDS. Report on the global HIV/AIDS epidemic: June 1998 [Internet]. 1998 [cited 2018 Apr 02]. Available from: http://data.unaids.org/pub/report/1998/19981125_global_epidemic_report_en.pdf

6. Negredo E, Back D, Blanco JR, Blanco J, Erlandson KM, Garolera M, et al. Aging in HIV-infected subjects: a new scenario and a new view. Biomed Res Int [Internet]. 2017 [cited 2018 Apr 02];2017:1-9. Available from: https://www.hindawi.com/journals/bmri/2017/5897298/

7. Jodelet D. Representações sociais: um domínio em expansão. In: Jodelet D (Org.). As representações sociais. Rio de Janeiro: EDUERJ; 2001. p. $17-44$.

8. Moscovici S. Representações sociais: investigação em psicologia social. 11ª ed. Petrópolis: Vozes; 2015.

9. Alexandre SG, Pereira MLD, Monte RS, Maia EG, Barbosa JSM, Moura SKB. Social representations of sexuality developed by women in the context of Aids. Rev Rene [Internet]. 2013 [cited 2018 Mar 22];14(1):120-9. Available from: http://www.revistarene.ufc.br/revista/index.php/ revista/article/view/39/pdf_1

10. Marcus U, Schink SB, Sherriff N, Jones AM, Gios L, Folch C, et al. HIV serostatus knowledge and serostatus disclosure with the most recent anal intercourse partner in a European MSM sample recruited in 13 cities: results from the Sialon-II study. BMC Infect Dis [Internet]. 2017 [cited 2018 Mar 22];17(1):730. Available from: https://www.ncbi.nlm.nih.gov/pubmed/29178847

11. Singh S, Song R, Johnson AS, McCray E, Hall HI. HIV incidence, HIV prevalence and undiagnosed HIV infections in men who have sex with men, United States. Ann Intern Med [Internet]. 2018 [cited 2018 Mar 22];17:2082. Available from: https://www.ncbi.nlm.nih.gov/ pubmed/29554663

12. Serra A, Sardinha AHL, Pereira ANS, Lima SCVS. Percepção de vida dos idosos portadores do HIV/Aids atendidos em centro de referência estadual. Saúde Debate [Internet]. 2013 [cited 2018 Mar 23];37(97):294-304. Available from: http://www.scielo.br/pdf/sdeb/v37n97/ v37n97a11.pdf

13. Cassétte JB, Silva LC, Felício EEAA, Soares LA, Morais RA, Prado TS, et al. HIV/Aids among the elderly: stigmas in healthcare work and training. Rev Bras Geriatr Gerontol [Internet]. 2016 [cited 2018 Mar 23];19(5):733-44. Available from: http://www.scielo.br/pdf/rbgg/v19n5/18099823-rbgg-19-05-00733.pdf

14. Renesto HMF, Falbo AR, Souza E, Vasconcelos MG. Coping and perception of women with HIV infection. Rev Saúde Pública [Internet]. 2014 [cited 2018 Mar 23];48(1):36-42. Available from: http://www.scielo.br/pdf/rsp/v48n1/en_0034-8910-rsp-48-01-0036.pdf

15. Seidl EMF, Faustino QM. Pessoas vivendo com HIV/Aids: possibilidades de atuação da psicologia. In: Seidl EMF, Miyazaki MCOS (Orgs.). Psicologia da saúde: pesquisa e atuação profissional no contexto de enfermidades crônicas. Curitiba: Juruá; 2014.

16. Silva LC, Felício EEAA, Cassétte JB, Soares LA, Morais RA, Prado TS, et al. Psychosocial impact of HIV/aids diagnosis on elderly persons receiving care from a public healthcare service. Rev Bras Geriatr Gerontol [Internet]. 2015 [cited 2018 Mar 23];18(4):821-33. Available from: http://www.scielo.br/pdf/rbgg/v18n4/1809-9823-rbgg-18-04-00821.pdf

17. Furtado FMSF, Santos JAG, Stedile L, Araújo E, Saldanha AAW, Silva J. 30 years later: social representations about AIDS and sexual practices of rural towns residents. Rev Esc Enferm USP [Internet]. 2016 [cited 2018 Mar 24];50(spe):71-7. Available from: http://www.scielo.br/pdf/ reeusp/v50nspe/0080-6234-reeusp-50-esp-0074.pdf 
18. Jodelet D. Loucuras e representações sociais. Petrópolis (RJ): Vozes; 2005.

19. Oliveira DC. Construction and transformation of social representations of AIDS and implications for health care. Rev Latino-Am Enfermagem [Internet]. 2013 [cited 2018 Mar 24];21(spe):276-86. Available from: http://www.scielo.br/pdf/rlae/v21nspe/34.pdf

20. Wagner TMC, Bosi DR. Mulheres com HIV/AIDS: reações ao diagnóstico. Contextos Clín [Internet]. 2013 [cited 2018 Mar 25];6(2):164-73. Available from: http://pepsic.bvsalud.org/pdf/cclin/v6n2/v6n2a10.pdf

21. Hipólito RL, Oliveira DC, Gomes AMT, Costa TL. Social representations of quality of life in HIV/AIDS: the role of time since diagnosis. Rev Enferm UERJ [Internet]. 2014 [cited 2018 Mar 26];22(6):753-9. Available from: http://www.e-publicacoes.uerj.br/index.php/enfermagemuerj/ article/view/12840/13474

22. Kaplan RL, Khoury CE, Field ERS, Mokhbat J. Living day by day: the meaning of living with HIV/AIDS among women in Lebanon. Glob Qual Nurs Res [Internet]. 2016 [cited 2018 Mar 26];3:1-13. Available from: http://journals.sagepub.com/doi/pdf/10.1177/2333393616650082

23. Santo CCE, Gomes AMT, Oliveira DC. A espiritualidade de pessoas com HIV/aids: um estudo de representações sociais. Rev Enf Ref [Internet]. 2013 [cited 2018 Mar 26];3(10):15-24. Available from: http://www.scielo.mec.pt/pdf/ref/vserllIn10/serllln10a03.pdf

24. Pinheiro CVQ, Medeiros NM. Práticas de prevenção do HIV/Aids e modos de subjetivação. Physis [Internet]. 2013 [cited 2018 Mar 27];23(2):629-46. Available from: http://www.scielo.br/pdf/physis/v23n2/v23n2a16.pdf

25. Persson A, Newman CE, Hopwood M, Kidd MR, Canavan PG, Kippax SC, et al. No ordinary mainstream illness: how HIV doctors perceive the virus. Qual Health Res [Internet]. 2014 [cited 2018 Mar 27]; 24(1):6-17. Available from: https://www.ncbi.nlm.nih.gov/pubmed/24259535

26. McGrath JW, Winchester MS, Kaawa-Mafigiri D, Walakira E, Namutiibwa F, Birungi J, et al. Challeging the paradigm: anthropological perspectives on HIV as a chronic disease. Med Anthropol [Internet]. 2014 [cited 2018 Mar 27];33(4):303-17. Available from: https://www. ncbi.nlm.nih.gov/pmc/articles/PMC4390365/pdf/nihms675502.pdf

27. Chirinos NEC, Meirelles BHS, Bousfield ABS. Relationship between the social representations of health professionals and people with tuberculosis and treatment abandonment. Texto Contexto Enferm [Internet]. 2017 [cited 2018 Mar 28];26(1):e5650015. 2017. Available from: http://www.scielo.br/pdf/tce/v26n1/0104-0707-tce-26-01-5650015.pdf

28. Ferreira MCG, Tura LFR, Silva RC, Ferreira MA. Social representations of older adults regarding quality of life. Rev Bras Enferm [Internet]. 2017 [cited 2018 Mar 28];70(4):806-13. Available from: http://www.scielo.br/pdf/reben/v70n4/0034-7167-reben-70-04-0806.pdf 